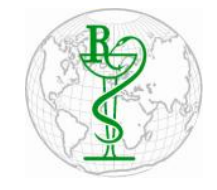

INDO GLOBAL JOURNAL OF

PHARMACEUTICAL SCIENCES

ISSN 2249- 1023

\title{
An Insight into Patents of Thiazolidinone Derivatives
}

\author{
Archana Sharma ${ }^{1 *}$, Vipin Kumar ${ }^{1,2^{*}}$, Sunil Kumar ${ }^{1}$, Dharam Pal Pathak ${ }^{3}$ \\ ${ }^{1}$ Institute of Pharmaceutical Sciences, Kurukshetra University, Kurukshetra-136119, India \\ ${ }^{2}$ School of Chemical Sciences and Pharmacy, Central University of Rajasthan, Bandarsindri, Kishangarh-305801, India \\ ${ }^{3}$ Delhi Institute of Pharmaceutical Sciences \& Research, New Delhi-110017, India
}

Address for Correspondance: Archana Sharma, archanakuk@gmail.com ; Vipin Kumar, vipbhardwaj@rediffmail.com

\begin{abstract}
Thiazolidinone derivatives have been a subject of continued exploration by the scientific community throughout the globe due to their diverse biological and other actions. Several methods for their synthesis have been reported in scientific literature. Biological screening of these compounds has shown that they possess a considerable potential as possible pharmacological agents. Several patents have also been granted related to these compounds. An earnest attempt has been made in this paper to compile important patents of thiazolidinone derivatives. We hope that the information provided in this paper will be useful and interesting to the prospective researchers and medicinal chemists involved in this arena. (C) 2014 iGlobal Research and Publishing Foundation. All rights reserved.
\end{abstract}

KEYWORDS: Heterocycle; Thiazolidinone; Patent.

\section{INTRODUCTION}

In the recent past, there has been a considerable interest and enthusiasm in developing novel small heterocyclic moieties possessing significant biological activities. The presence of thiazole moiety in the structure of several naturally occurring molecules with important antibiotic, immunosuppressive and antitumor activities has been well known for long $[1,2]$.

Small ring heterocycles containing nitrogen, sulfur and oxygen have been under investigation for a long time because of their important medicinal properties [3]. Thiazolidinone template is one of the privileged structural fragments in modern medicinal chemistry having broad pharmacological spectrum and affinity for various biotargets [4]. The presence of thiazolidinone moiety in the structure of several naturally occurring molecules with important antibiotic, immunosuppressive and antitumor activities has been known for several years. Many thiazolidinone derivatives have shown excellent bactericidal, fungicidal, anthelmintic, anticonvulsant and anticancer activities [5].
Some derivatives of 4-thiazolidinones can be used for treatment of cardiac diseases. Modifications on 2,3 and 5 positions of 4-thiazolidinone give out antidiabetic drugs and potent aldose reductase inhibitors, which are used in the treatment of diabetic complications like cataracts, neuropathy, nephropathy etc [6].<smiles>O=C1CSCN1</smiles>

Figure-1

4-Thiazolidinones are derivatives of thiazolidine with a carbonyl group at the $4^{\text {th }}$ position. Substituents at the 2, 3 and 5 positions may be varied, but the 


\section{Indo Global Journal of Pharmaceutical Sciences, 2015; 5(1): 12-18}

greatest difference in structure and properties is exerted by the group attached to the carbon atom at the $2^{\text {nd }}$ position. Variations in the substituents attached to the nitrogen atom and the methylene carbon atom are possible [7].

The diverse and significant activity profile of thiazolidinones has established them as pharmacologically most active scaffolds. A large number of biological activities such as antimicrobial [8], anticonvulsant [9], antitubercular [10], anticancer [11,12], anti-inflammatory and analgesics $[13,14]$, anti-HIV [15,16], antioxidant [17] activities etc., have been reported to be associated with thiazolidinone [18].

\section{PATENTS RELATED TO THIAZOLIDINONES}

The development of new synthetic methods leading to structures, which incorporates various biologically active moieties in a single molecule, has attracted much attention in organic chemistry. In particular, heterocyclic compounds hold a special place among pharmaceutically active products, and the development of simple and efficient synthesis of compounds incorporating multi heterocyclic rings has given a new dimension to the drug discovery [19]. Over the past few decades, number of patents has been issued in the field of thiazolidinones a with a varied range of biological and other activities. The present paper is an earnest attempt to compile the important patents granted to thiazolidinone derivatives, with an objective that the information provided herein will be useful to the prospective researchers in this field.

Table 1. Different Patents Filed on Thiazolidinone Derivatives

\begin{tabular}{|c|c|c|c|c|}
\hline Sr. No. & Date & Patent Number & Invention Disclosed & Reference \\
\hline 1) & Feb/21/2012 & US 8119812 B2 & $\begin{array}{l}\text { The compounds of the invention inhibited the CDC7 } \\
\text { protein kinase activity, and suppression of cell } \\
\text { proliferation. }\end{array}$ & 20 \\
\hline 2) & Aug/23/2011 & US 8003678 B2 & $\begin{array}{l}\text { Therapeutic methods, compositions, and medicaments } \\
\text { related thereto of thiazolidinones, oxazolidinones and } \\
\text { related compounds are disclosed }\end{array}$ & 21 \\
\hline 3) & Aug/04/2011 & $\begin{array}{l}\text { US } 2010190299 \\
\text { A1 }\end{array}$ & $\begin{array}{l}\text { Novel thiazolidinone derivative having a CDC7 } \\
\text { inhibitory action. }\end{array}$ & 22 \\
\hline 4) & Feb/17/2011 & US 0039849 A1 & $\begin{array}{l}\text { 5-Substituted-2-imino-thiazolidinone compounds and } \\
\text { their use as inhibitors of bacterial infection }\end{array}$ & 23 \\
\hline 5) & Aug/31/2010 & US 7786117 B2 & $\begin{array}{l}\text { Therapeutic substituted thiazolidinones, oxazolidinones } \\
\text { and related compounds }\end{array}$ & 24 \\
\hline 6) & Aug/24/2010 & US 7781465 B2 & $\begin{array}{l}\text { Therapeutic methods, compositions, and medicaments } \\
\text { related to oxazolidinones and thiazolidinones have } \\
\text { been described }\end{array}$ & 25 \\
\hline 7) & Feb/16/2010 & US 7662842 B2 & $\begin{array}{l}\text { Thiazolidinones amides, thiazolidine carboxylic } \\
\text { acidamides, and serine amides including polyamine } \\
\text { conjugates thereof, as selective anti-cancer agents }\end{array}$ & 26 \\
\hline 8) & Oct $/ 23 / 2008$ & $\begin{array}{l}\text { US } 20080261980 \\
\text { A1 }\end{array}$ & $\begin{array}{l}\text { The invention describes the use of compounds for the } \\
\text { preparation of pharmaceutical compositions for the } \\
\text { treatment of pathologies in which inhibition of the } \\
\text { interaction between HIF- } 1 \alpha \text { and p } 300 \text { is beneficial, in } \\
\text { particular as antiangiogenic medicaments for the } \\
\text { therapy of solid tumors. }\end{array}$ & 27 \\
\hline 9) & Mar/22/2007 & US 0066597 A1 & $\begin{array}{l}\text { Thiazolidinone, oxazolidinone, imidazolone derivatives } \\
\text { for treating lower urinary tract and related disorders }\end{array}$ & 28 \\
\hline 10) & Feb/15/2007 & US 0037862 A1 & $\begin{array}{l}\text { Thiazolidinones, their production and uses as } \\
\text { pharmaceutical agents as inhibitors of polo kinases in } \\
\text { cancer, auto-immune diseases, cardiovascular diseases }\end{array}$ & 29 \\
\hline 11) & Jan/30/2007 & US 7169782 B2 & Aryl substituted thiazolidinones and the use thereof & 30 \\
\hline 12) & Jan/18/2007 & US 0015759 A1 & $\begin{array}{l}\text { Metasubstituted thiazolidinones, their manufacture and } \\
\text { use as a drug }\end{array}$ & 31 \\
\hline 13) & Jan/11/2007 & US 0010565 A1 & New thiazolidinones without basic nitrogen, their & 32 \\
\hline
\end{tabular}


Indo Global Journal of Pharmaceutical Sciences, 2015; 5(1): 12-18

\begin{tabular}{|c|c|c|c|c|}
\hline & & & production and use as pharmaceutical agents & \\
\hline 14) & Jan/11/2007 & US 0010566 A1 & $\begin{array}{l}\text { Thiazolidinones without basic nitrogen, their } \\
\text { production and use as pharmaceutical agents }\end{array}$ & 33 \\
\hline 15) & Apr/13/2006 & US $0079503 \mathrm{~A} 1$ & $\begin{array}{l}\text { Thiazolidinones and the use thereof as polo-like kinase } \\
\text { inhibitors }\end{array}$ & 34 \\
\hline 16) & Feb/23/2006 & US 0040998 A1 & $\begin{array}{l}\text { Thiazolidinone amides, thiazolidine carboxylic acid } \\
\text { amides, methods of making, and uses thereof }\end{array}$ & 35 \\
\hline 17) & Jul/07/2005 & US 0148587 A1 & $\begin{array}{l}\text { Thiazolidinones, oxazolidinone, and imidazolone } \\
\text { derivatives for treating lower urinary tract and related } \\
\text { disorders }\end{array}$ & 36 \\
\hline 18) & May/26/2005 & US 0113421 & $\begin{array}{l}\text { Thiazolidinones, oxazolidinone, and imidazolone } \\
\text { derivatives for treating non-inflammatory } \\
\text { gastrointestinal tract disorder }\end{array}$ & 37 \\
\hline 19) & Nov/23/2004 & US 6821991 B2 & $\begin{array}{l}\text { 2-Substituted thiazolidinones as beta-3 adrenergic } \\
\text { receptor agonists }\end{array}$ & 38 \\
\hline 20) & Sep/09/2004 & US 0176364 A1 & Aryl substituted thiazolidinones and the use thereof & 39 \\
\hline 21) & May/20/2004 & US 0097566 A1 & $\begin{array}{l}\text { 2-Substituted thiazolidinone and oxazolidinone } \\
\text { derivatives for the inhibition of phosphatases and the } \\
\text { treatment of cancer }\end{array}$ & 40 \\
\hline 22) & Jun/24/2003 & US 6583140 B2 & $\begin{array}{l}\text { 2-Substituted thiazolidinones as beta-3 adrenergic } \\
\text { receptor agonists }\end{array}$ & 41 \\
\hline 23) & Jan/14/2003 & US $6506751 \mathrm{~B} 1$ & $\begin{array}{l}\text { Thiazolidinone compounds useful as chemokine } \\
\text { inhibitors }\end{array}$ & 42 \\
\hline 24) & Sept/04/2001 & US 6284775 B1 & $\begin{array}{l}\text { 3-[4-Substituted-4-piperazinyl)butyl]-thiazolidin-4-one } \\
\text { and related compounds }\end{array}$ & 43 \\
\hline 25) & Aug/27/1996 & US 5549974 & $\begin{array}{l}\text { Methods for the solid phase synthesis of } \\
\text { thiazolidinones, metathiazanones and derivatives } \\
\text { thereof }\end{array}$ & 44 \\
\hline 26) & Dec/26/1995 & US 5478852 & $\begin{array}{l}\text { Use of thiazolidindione derivatives and related } \\
\text { antihyperglycemic agents in the treatment of impaired } \\
\text { glucose tolerance in order to prevent or delay the onset } \\
\text { of noninsulin-dependent diabetes mellitus }\end{array}$ & 45 \\
\hline 27) & Oct/10/1995 & US 5457109 & $\begin{array}{l}\text { Use of thiazolidinedione derivatives and related } \\
\text { antihyperglycemic agents in the treatment of disease } \\
\text { states at risk for progeressing to noninsulin-dependent } \\
\text { diabetes mellitus }\end{array}$ & 46 \\
\hline 28) & Dec/06/1994 & US 5371087 & $\begin{array}{l}\text { Thiazolidinones derivatives as antipsychotic, } \\
\text { analgesics, anticonvulsant and anxiolytic agent have } \\
\text { been described }\end{array}$ & 47 \\
\hline 29) & $\mathrm{Jul} / 20 / 1993$ & US 5229388 & $\begin{array}{l}\text { 3-[4-(1-Substituted-4-piperazinyl) butyl]-4- } \\
\text { thiazolidinone and related compounds }\end{array}$ & 48 \\
\hline 30) & May/04/1993 & US 5208250 & $\begin{array}{l}\text { Known and selected novel arylmethylenyl derivatives } \\
\text { of thiazolidinones, imidazolidinones and } \\
\text { oxazolidinonesuseful as antiallergy agents and anti- } \\
\text { inflammatory agents }\end{array}$ & 49 \\
\hline 31) & Sep/01/1992 & US 5143929 & $\begin{array}{l}\text { 2-Substituted thiazolidinone, oxazolidinone, and } \\
\text { imidazolidinone as anti-inflammatory agents }\end{array}$ & 50 \\
\hline 32) & Sep/01/1992 & US 5143928 & $\begin{array}{l}\text { 3,5-Di-tertiarybutyl-4-hydroxy-phenylmethylene } \\
\text { derivatives of substituted thiazolidinones, } \\
\text { oxazolidinones, and imidazolidinones as anti- } \\
\text { inflammatory agents }\end{array}$ & 51 \\
\hline 33) & Aug/04/1992 & US 5136037 & $\begin{array}{l}\text { 3-[4-(Substituted-4-piperazinyl)butyl]-4-thiazolidinone } \\
\text { and compounds }\end{array}$ & 52 \\
\hline 34) & Oct/29/1991 & US 5061720 & $\begin{array}{l}\text { Novel substituted 4-thiazolidinone deriva } \\
\text { tives having cyclooxygenase and 5-lipoxygenase } \\
\text { inhibiting properties and which are topical }\end{array}$ & 53 \\
\hline
\end{tabular}


Indo Global Journal of Pharmaceutical Sciences, 2015; 5(1): 12-18

\begin{tabular}{|c|c|c|c|c|}
\hline & & & $\begin{array}{l}\text { antiinfammatory } \\
\text { agents for infammed conditions of the skin }\end{array}$ & \\
\hline 35) & Aug/06/1991 & US 5037984 & $\begin{array}{l}\text { 3-[4-(1-substituted-4-piperazinyl)-butyl]-4- } \\
\text { thiazolidinone compounds }\end{array}$ & 54 \\
\hline 36) & Oct/10/1989 & US 4873255 & $\begin{array}{l}\text { Thiazolidinone derivatives, their preparation and their } \\
\text { use }\end{array}$ & 55 \\
\hline 37) & May/12/1987 & US 4664694 & $\begin{array}{l}\text { Substituted thiazolidinones useful as plant growth } \\
\text { regulators. Compound is useful in regulating the } \\
\text { growth of plants and can be formed int a composition, } \\
\text { useful in this application. The composition comprises } \\
\text { the compound having the structural formula given } \\
\text { above and an inert carrier therefor. }\end{array}$ & 56 \\
\hline 38) & Jan/27/1987 & US 4639460 & $\begin{array}{l}\text { Fungicidal substituted } \mathrm{N} \text {-(1-iodopropargyl) } \\
\text { thiazolidinones have been disclosed. }\end{array}$ & 57 \\
\hline 39) & Aug/13/1985 & US 4535164 & $\begin{array}{l}\text { Process for preparing certain substituted } 4 \text { - } \\
\text { thiazolidinones in an aprotic reaction medium in the } \\
\text { presence of a metal catalyst. }\end{array}$ & 58 \\
\hline 40) & April/17/1984 & US 4443455 & $\begin{array}{l}\text { A process for combating plant fungi with a } \\
\text { thiazolidinone having pesticidal and plant growth } \\
\text { regulating properties; and to methods for making them } \\
\text { have been disclosed, }\end{array}$ & 59 \\
\hline 41) & April/17/1984 & US 4443454 & $\begin{array}{l}\text { This invention relates to thiazolidinone compounds, } \\
\text { having pesticidal and plant growth regulating } \\
\text { properties; and to methods for making them. }\end{array}$ & 60 \\
\hline 42) & Dec/13/1977 & US 4062859 & $\begin{array}{l}\text { The preparation and use of halogenated 3- } \\
\text { isothiazolidinone 1-oxides and 1,1-dioxides are } \\
\text { disclosed. These compounds and compositions } \\
\text { containing them are useful in controlling weeds and } \\
\text { microorganisms such as bacteria, fungi, algae and the } \\
\text { like. }\end{array}$ & 61 \\
\hline 43) & Oct/11/1977 & US 4053471 & $\begin{array}{l}\text { 4-Thiazolidinone derivatives, their synthesis and } \\
\text { biolgoical importance have been described. }\end{array}$ & 62 \\
\hline 44) & Jun/29/1976 & US 3912749 & $\begin{array}{l}\text { 2-(Carbamoyloximino)-4-thiazolidinone compounds as } \\
\text { insecticidal, miticidal or nematocidal agents }\end{array}$ & 63 \\
\hline 45) & Dec/10/1974 & US 3853902 & $\begin{array}{l}\text { Haloalkyl-4-thiazolidinone useful as plasticizers and in } \\
\text { some instances as plant hormones. }\end{array}$ & 64 \\
\hline 46) & April/28/1970 & US 3509231 & $\begin{array}{l}\text { Oxazolidinones and thiazolidinones as latent } \\
\text { catalystsfor curing polyepoxide resins have been } \\
\text { described }\end{array}$ & 65 \\
\hline 47) & Mar/14/1967 & US 3309377 & $\begin{array}{l}\text { 3-[(2-oxazolidinone-3-yl)-alkyl]-4-thiazolidinones and } \\
\text { their preparation }\end{array}$ & 66 \\
\hline 48) & Jun/01/1965 & US 3187002 & $\begin{array}{l}\text { The substituted 4-thiazolidinones of this invention have } \\
\text { been found to have interesting pharmacological activity } \\
\text { as analgesics, sedatives, anti-inilammatory agents and } \\
\text { choleretic agents. In use, they may be formulated with } \\
\text { conventional pharmaceutical carriers to form such } \\
\text { typical dosage units as tablets, capsules, solutions, } \\
\text { suspensions, suppositories and the like. These new and } \\
\text { novel compounds are also valuable intermediates } \\
\text { useful in the production of additional new and novel 4- } \\
\text { thiazolidinones and bis(4-thiazolidinones) which in } \\
\text { turn have interesting pharmacological activity. }\end{array}$ & 67 \\
\hline 49) & May/04/1965 & US 3182063 & $\begin{array}{l}\text { Describes compositions of matter classified in the art } \\
\text { of chemistry as substituted 4-thiazolidinones and to } \\
\text { processes for making such compositions }\end{array}$ & 68 \\
\hline 50) & Jan/08/1963 & US 3072653 & 5-Amino derivative of 4-thiazolidinones and process & 69 \\
\hline
\end{tabular}


Indo Global Journal of Pharmaceutical Sciences, 2015; 5(1): 12-18

\begin{tabular}{|c|l|l|l|l|}
\hline & & & therefor & \\
\hline 51) & Jan/08/1963 & US 3072670 & $\begin{array}{l}\text { Amides of substituted 4-thiazolidinones and process } \\
\text { therefor }\end{array}$ & 70 \\
\hline 52) & Jan/08/1963 & US 3072671 & $\begin{array}{l}\text { Describes synthesis of new and novel substituted bis(4- } \\
\text { thiazolidinones) and process therefor }\end{array}$ & 71 \\
\hline
\end{tabular}

\section{INTRODUCTION}

A large number of patents have been granted to thiazolidinones and their derivatives in diverse fields. Important patens of last five decades have been compiled herein, which demonstrate the versatile utiltity of these compounds. It is evident that thiazolidinones have been a subject of significant interest of medicinal chemist and other researchers. A number of scientific endeavours have been undertaken to harness the maximum potential of this moiety. It is anticipated that further scientific and systematic research on these compounds will enable the researchers to utilize the maximum therapeutic potential of these agents.

\section{ACKNOWLEDGEMENTS}

University Grants Commission (UGC), New Delhi, India, is duly acknowledged for the grant of fellowship (JRF in ET) to Ms. Archana Sharma. Prof. A.C. Rana, Director, Institute of Pharmaceutical Sciences, Kurukshetra University, Kurukshetra, is acknowledged for providing necessary facilities.

\section{REFERENCES}

1. Vagdevi, H.M., Vaidya, V.P., Latha, K.P., Padmashali, B. Syntheis and pharmacological examination of some thiazolidinone derivatives of naptho[2,1-b]furan. Ind. J. Pharm. Sci., 2006; 68: 719-725.

2. Kumar V, Sharma A, Sharma PC. Synthesis of some novel 2,5disubstituted thiazolidinones from a long chain fatty acid as possible anti-inflammatory, analgesic and hydrogen peroxide scavenging agents. J. Enz. Inhib. Med. Chem., 2011; 26(2): 198-203. DOI 10.3109/14756366.2010.489897.

3. Turgut, Z., Yolacan, C., Aydogan, F., Bagdatli, E., Ocal, N. Synthesis of New Pyrazolothiazole Derivatives from 4Thiazolidinones, Molecules, 2007; 12: 2007, 2151-2159.

4. Havrylyuk, D., Zimenkovsky, B., Vasylenko, O., Zaprutko, L., Gzella, A. Lesyk, R. Synthesis of novel thiazolone-based compounds containing pyrazoline moiety and evaluation of their anticancer activity. Eur. J. Med. Chem., 2009; 44(4): 1396-1404.

5. Khan, S.A., Yusuf, M. Synthesis and biological evaluation of some thiazolidinone derivatives of steroid as antibacterial agents. Eur. J. Med. Chem., 2009;44(6): 2597-2600.

6. Ameta, U., Ojha, S., Bhambi, D., Talesara, G.L. Synthetic studies on some 3-[(5-arylidene-4-oxo-1,3-thiazolidin-2yliden)amino]-2-phenylquinazolin-4(3H)-ones and their ethoxyphthalimide derivatives. ARKIVOC, 2006; (xiii): 83-89.

7. Verma, A., Saraf, S.K. 4-Thiazolidinone :A biologically active scaffold. Eur. J. Med. Chem., 2008; 43: 897-905.

8. Ozkirimli, S., Kazan, F., Tunali, Y. Synthesis, antibacterial and antifungal activities of $3-(1,2,4-$ triazole-3-yl)-4-thiazolidinones. J. Enz. Inhib. Med. Chem. 2009; 24: 447-452.

9. Shiradkar, M.R., Ghodake, M., Bothara, K.G., Bhandari, S.V., Nikalje, A., Akula, K.C., Desai, M.C., Burange, P.J. Synthesis and anticonvulsant activity of clubbed thiazolidinone-barbituric acid thiazolidinone-triazole derivatives. ARKIVOC, 2007; (xiv): 58-74.

10. Parekh, H.H., Parikh, K.A., Parikh, A.R. Synthesis of some 4-thiazolidinone derivatives as antitubercular agents. J. Sci. I.R. Iran, 2004; 15: 143-148.

11. Zhou, H., Wu, S., Zhai, S., Liu, A., Sun, W., Li, R., Zhang, Y., Ekins, S., Swaan, P.W., Fang, B., Zhang, B., Yan, B. Design, synthesis, cytoselective toxicity, structure activity relationship, and pharmacophore of thiazolidinone derivatives targeting drug resistant lung cancer cells. J. Med. Chem., 2008; 51: 1242-1251.

12. Gududuru, V., Dalton, T., Miller, D. Discovery of 2arylthiazolidine-4-carboxylic acid amides as new class of cytotoxic agents for prostate cancer. J. Med. Chem., 2005; 48: 2584-2588.

13. Geronikaki, A.A., Lagunin, A.A., Hadjipablou-Litina, D.I., Eleftheriou, E.T., Filimonov, D.A., Poroikov, V.V., Alam, I., Saxena, A.A. Computer-aided discovery of anti-inflammatory thiazolidinones with dual cyclooxygenase/lipoxygenase inhibition. J. Med. Chem., 2008; 51: 1601-1609.

14. Kumar, A., Rajput, C.S., Bhati, S.K. Synthesis of 3-[4̀(p-chlorophenyl)-thiazol-2-yl]-2-

[(substitutedazetidinone/thiazolidinone)-aminoethyl]6-bromoquinazoline-4-ones as anti-inflammatory agent. Bioorg. Med. Chem., 2007; 15: 3089-3096.

15. Balzarini, J., Orzeszko, B., Maurin, J.K., Orzeszko, A. Synthesis and anti-HIV studies of 2-adamantylsubstituted thiazolidin-4-ones. Eur. J. Med. Chem. 2007; 42: 993-1003.

16. Rawal, R.K., Kumar, A., Siddiqi, M., Kutti, S.B. Molecular docking studies on 4-thiazolidinones as HIV-1 RT inhibitors. J. Mol. Model., 2007; 13: 155161.

17. Kato, T., Ozaki, T., Ohi, N. Novel calcium antagonists with both calcium overload inhibition and antioxidant activity. 2. structure-activity relationships of thiazolidinone Derivatives. J. Med. Chem. 1999; 42: 3134-3146.

18. Sharma, A., Kumar, V., Jain, S., Sharma, P,C. Thiazolidin-4-one and hydrazone derivatives of capric acid as possible anti-inflammatory, analgesic and hydrogen peroxide-scavenging agents. J. Enz. Inhib. Med. Chem., 2011; 26(4): 546-552.

19. Shelke, S.H., Mhaske, P.C., Nandave, M., Narkhade, S., Walhekar, N.M., Bobade, V.D. Synthesis and pharmacological evaluation of a novel series of3-aryl-2-(2-substituted-4methylthiazole-5-yl)thiazolidin-4-one as possible anti- 


\section{Indo Global Journal of Pharmaceutical Sciences, 2015; 5(1): 12-18}

inflammatory and antimicrobial agents. Bioorg. Med. Chem. Lett., 2012; 22: 6373-6376.

20. Irie, T., Sawa, M., Ito, S., Tanaka, C., Ro, S. G., Park. H. C. Thiazolidinone derivative. U.S. Patent US8119812, B2, Feb 21, 2012.

21. Old, W. D. Therapeutic substituted thiazolidinones, oxazolidinones, and related compounds. U.S. Patent US 8003678, B2, Aug 23, 2011.

22. Irie, T., Sawa, M., Ito, S., Tanaka, C., Ro, S. G., Park. H. C. Thiazolidinone derivative. U.S. Patent US 0190299, A1, Aug 4, 2011.

23. Felise, H. B., Miller, S. I., Kline, M. I., 5-substituted-2-iminothiazolidinonecompounds and their use as inhibitors ofbacterial infection. U.S. Patent US 0039849, A1, Feb 17, 2011.

24. Old, W. D., used for treating glaucoma, inflammatory bowel disease and alopecia. U.S. Patent US7786117, B2, Aug 31, 2010.

25. Old, W. D., Therapeutic oxazolidinones andthiazolidinones. U.S. Patent US7781465, B2, Aug 24, 2010.

26. Miller, D. D., Dalton, J. T., Gududuru, V., Hurh, E. (4R)-2-(4methoxyphenyl)-N-octadecylthiazolidine-4-carboxamide; antiacarcinogenic agent for destroying a melanoma cell. U.S. Patent US7662842, B2, Feb 16, 2010.

27. Mara, C., Gennaro, C., Sergio, D. M., Mario, G., Use of Thiazolidinone Derivatives as Antiangiogenic Agents. U.S. Patent US 0261980, A1, Oct 23,2008.

28. Fraser, M., Thor, K., Burgard, E., Thiazolidinone, oxazolidinone, andimidazolone derivatives for treating lowerurinary tract and related disorders. U.S. Patent US0066597, A1, 22 Mar, 2007.

29. Siemeister, G., Briem, H., Schulze, V., Eis, K., Wortmann, L., Schwede, W., Schneider, H., Eberspaecher, V., Stumpp H. H. inhibitors of polo-like kinases; (4,4-Dimethyl-4,5-dihydrooxazol-2-yl)-[3-ethyl-4-oxo-5-[1-[3-(2-pyrrolidin-1-yl-ethyl)phenylamino]-meth-(E/Z)-ylidene]-thiazolidin-(2-(E or Z))ylidene]-acetonitrile; cancer, auto-immune diseases, cardiovascular diseases. U.S. Patent US0037862, A1, 0037862 A1.

30. Sun, Q., Kyle, D. J., Gharagozloo, P., Yang, J., Aryl substituted thiazolidinones and the usethereof. U.S. Patent US7169782, B2, 30 Jan, 2007.

31. Schulze, V. K., Eis, K., Wortmann, L., Kosemund, D., Prien, O., Siemeister, G., -Stumpp, H. H., Eberspaecher, U., Brittain, D. E. A., Islam, I., Metasubstituted thiazolidinones, their manufacture and use as a drug. U.S. Patent US0015759, A1, Jan 18, 2007.

32. Schulze, V. K., Eis, K., Wortmann, L., Kosemund, D., Prien, O., Siemeister, G., -Stumpp, H. H., Eberspaecher, U., Guenther, J., Brittain, D. E. A., New thiazolidinones without basic nitrogen, their production and use as pharmaceutical agents. U.S. Patent US0010565, A1, Jan 11, 2007.

33. Schulze, V. K., Eis, K., Wortmann, L., Kosemund, D., Prien, O., Siemeister, G., -Stumpp, H. H., Eberspaecher, U., Guenther, J., Brittain, D. E. A., Thiazolidinones without basic nitrogen, their production and use as pharmaceutical agents. U.S. Patent US0010566, A1, Jan 11, 2007.

34. SchWede, W., Schulze, V., Eis, K., Buchmann, B., Briem, H., Siemeister, G., Boemer, U., Parczyk, K., Thiazolidinones and the use therof as polo-like kinase inhibitors.U.S. Patent US0079503, A1, Apr 13, 2006.

35. Miller, D. D., Gududuru, V., Dalton, J.T., Hurh, E., Thiazolidinone amides,thiazolidine carboxylic acid amides, methods of making, and uses there of. U.S. Patent US0040998, A1, Feb 23, 2006.

36. Oliver, M., Bruce, K., Edward, C. Thiazolidinone, oxazolidinone, and imidazolone derivatives for treating lower urinary tract and related disorders . US Patent 0148587A1, July 07, 2005.

37. Fraser, M.O., Landau,S.B., Burgard,E.C., Thiazolidinone, oxazolidinone, and imidazolone derivatives for treating non-inflammatory gastrointestinal tract disorders. U.S. Patent US0113421, A1, May 26, 2005.

38. $\mathrm{Hu}, \mathrm{B}$, , 2-Substituted thiazolidinones as $\beta-3$ adrenergic receptor agonists. U.S. Patent US 6821991, B2, Nov 23, 2004.

39. Sun, Q., Kyle, D.J., Aryl substituted thiazinidinones aryl substituted thiazinidinones. U.S. Patent US 0176364, A1, SeP 9, 2004.

40. Al-Shamma, H. A., Bao, H., Cow, C. N., Fanjul, A.N., Pfah, M., D. P. M., Spruce, L.W., Tachdjian, C., Wiemann, T. R., Zapt, J. W., 2-Substituted thiazolidinone and oxazolidinone derivatives for the inhibition of phosphatases and the treatment of cancer. EP 1463718, A1, Oct 6, 2004.

41. $\mathrm{Hu}, \mathrm{B}$., 2-Substituted thiazolidinones as beta-3 adrenergic receptor agonists. U.S. Patent US6583140, B2, Jun 24, 2003.

42. Justus, S. E. A., Lee,H. T., Pontrello, J. K., Roth, B. D., Sexton, K. E., Wilson, M. W., Thiazolidinone compounds useful as chemokine inhibitors. U.S. Patent US6506751 B1, Jan 14, 2003.

43. Hrib, N. J., Jurcak J. G., 3-[4-Substituted-4piperazinyl)butyl]-thiazolidin-4-one and related compounds. U.S. Patent US6284775, B1, Sep 4, 2001.

44. Holmes, C.P. Methods for solid phase synthesis thiazolidinones, metathiazones and derivatives thereof. U.S. Patent 3655549974, Aug 27, 1996.

45. Olefsky, J., Antonucci, T., Lockwood, D., Norris, R. Use of thiazolidinone derivatives and related antihypergylemic agents in the treatment of impaired glucose tolerance in order to prevent or delay onset of non insulin dependent diabetes mellitus. U.S. Patent 5478852, Dec 26, 1995.

46. Antonucci, T. Use of thiazolidinedione derivatives and related antihyperglycemic agents in the treatment of disease states at risk for progressing to noninsulindependent diabetes mellitus. U.S. Patent 5457109, Octt 10, 1995.

47. Hrib, N.J., Jurcak, J.G. Antipsychotic, analgesics, anticonvulsant and anxiolytic agent. U.S. Patent 5371087A, Dec 6, 1994.

48. Hrib, N.J., Jurcak, J.G 3-[4-(1-Substituted4 piperazinyl) butyl]-4-thiazolidinone and related compounds. U.S. Patent 5229388, Jul 20, 1993.

49. Cetenko, W.A., et al. Known and selected novel arylmethylenyl derivatives of thiazolidinones, imidazolidinones and oxazolidinones useful as antiallergy agents and anti-inflammatory agents. U.S. Patent 5208250, May 04, 1993.

50. Belliotti T.R., et al. 2-Substituted thiazolidinone oxazolidinone, and , otherupublications imidazolidinone derivatives of fenamates as antiinflammatory agents. U.S. Patent 5142393, Sep 01, 1992. 


\section{Indo Global Journal of Pharmaceutical Sciences, 2015; 5(1): 12-18}

51. Cetenko, W.A., Connor, D.T., Sircar, J.C., Sorenson, R.J., Unangst, P.C. 3,5-Di-tertiarybutyl-4-hydroxy phenylmethylene derivatives of 2-substituted thiazolidinones, oxazolidinones, and imidazolidinones as antiinflammatory agents. U.S. Patent 5143928, Sep 01, 1992.

52. Hrib, N.J., Jurcak, J.G. 3-(4-substituted -4-piperazinyl) butyl-4-thiazolidinone and related compounds. U.S. Patent 5136037, Aug 4, 1992.

53. Walsh, D.A., Uwaydah, I.M. Substituted-4thiazolidinone derivatives. U.S. Patent 5061720, Oct 29, 1991.

54. Hrib, N.J., Jurcak, J.G. 3-[4-(1-Substituted-4piperazinyl) butyl]-4-thiazolidinone compounds. U.S. Patent 5061720, Oct 29, 1991.

55. Takao Yoshioka, T. Kauai, T., Aizawa, Y., Horikoshi, H., Hasegawa, K. Thiazolidinone derivatives, their preparation and their use. U.S. Patent 4873255 , Oct 10, 1989.

56. Brouwer W.G. Substituted thiazolidinones useful as plant growth regulators. U.S. Patent 4664694, May 12,1987 .

57. Rose, B.F. Fungicidal substituted n-(1iodopropargyl)thiazolidinones. U.S. Patent 46639460, Jan 27, 1987.

58. Pardo, R.M., Bock, M.G. Cyclization of amidecontaining thioketal-thioacetal using aprotic solvent and mercuric salt catalyst. U.S. Patent 4535164, Aug $13,1985$.

59. Worthington, P.A., Fungicidal Thiazolidinone. U.S. Patent 4443455, April 17. 1984.

60. Worthington, P.A., Thiazolidinones. U.S. Patent 4443454, Apr 17, 1984.
61. Weiler, E.D., Miller G.A. Halogenated 3isothiazolidinone-1-oxide and 1,1-dioxide. U.S. Patent 4062859, Dec 13, 1977.

62. Krapcho, J., Somerset, N.J. 4-Thiazolidinone derivatives. U.S. Patent 4053471, Oct 11, 1977.

63. D‘Silva, T.D.J. Z-(carbamoyloximinol-4-v thiazolidinone compounds as insecticidal, miticidal or nematocidal agents. U.S. Patent 3,966,953, Jun 29,1976.

64. Raasch, M.S. Haloalkyl-4-thiazolidinone. U.S. Patent 3853902, Dec 10, 1974.

65. Dan E. Ranck, D.E., Sanford, and Safranski, J.C., Mich, M. Oxazolidinones and thiazolidinones as latent catalysts for curing polyep oxide resins. U.S. Patent 3,509,231, Apr 28, 1970.

66. Surrey, A.R., Albany, N.Y 3-[(2-oxazolidinone-3-yl)alkyl]-4-thiazol idinones and their preparation U.S. Patent 3,309,377, Mar 14, 1967.

67. Satzinger, G. Substituted 4-theazoledenones and process therefor. U.S. Patent 3,18,7002, Jun 1, 1965.

68. Satzinger, G., Memmingen, Allgau, Germany. Substituted 4-thiazolhdinones and proces therefor. Gerhard Satzinger, Memmingen, Aligau . U.S. Patent 3,182,063, May 4, 1965.

69. Satzinger, G., 5-Amino derivatives of 4thiazolidinones and process therefor U.S. Patent 3,072,653, Jan 8, 1963.

70. Satzinger, G. Amides of substituted 4-thiazolidinones and process therefor. U.S. Patent 3,072,670, Jan. 8, 1963.

71. Satzinger, G., Memmingen, Allgau, Germany. Substituted bis(4-thiazolidin ones) and process therefor. Memingen, U.S. Patent 3,072,671, Jan. 8, 1963.

Indo Global Journal of Pharmaceutical Sciences( ISSN 22491023 ; CODEN- IGJPAI; NLM ID: 101610675) indexed and abstracted in EMBASE(Elsevier), SCIRUS(Elsevier),CABI, CAB Abstracts, Chemical Abstract Services(CAS), American Chemical Society(ACS), Index Copernicus, EBSCO, DOAJ, Google Scholar and many more. For further details, visit 